\title{
Music in Basic Education: Contribution to the Teaching of Environmental Education in Northeast Brazil
}

\author{
Clecia Maria Gomes Freitas ${ }^{1}$, Múcio Luiz Banja Fernandes, ${ }^{2, *}$ \\ ${ }^{1}$ Mestra em Educação pela Universidade de Pernambuco-Campus Mata Norte \\ Brazil \\ ${ }^{2}$ Mestrado em Profissional em Educação da Universidade de Pernambuco \\ Brazil \\ ${ }^{*}$ Corresponding author's email: mucio.banja [AT] upe.br
}

\begin{abstract}
This research investigated perspectives of Environmental Education through the lyrics of songs with environmental themes in Elementary School in a school in northeastern Brazil. This was done using a qualitative and quantitative approach to data collection, through action research, questionnaires and interviews. The questionnaires were composed of 08 qualitative questions about lyrics and their approaches on the theme and environmental perception. The questionnaires were applied to 30 students of the 9 th year of Elementary School in a public school. The results of this investigation showed the use of lyrics of the songs. $63 \%$ of the students answered what most drew attention in the theme used in music as the word pollution and its cause with the death of nature. It was concluded that the use of ecological songs in the classroom proved to be quite effective as an educational tool, improving the quality of the classes in a simple and dynamic way, thus awakening the students' awareness for issues related to preserving the environment.
\end{abstract}

Keywords---- Environmental Education, Music, Elementary Education

\section{INTRODUCTION}

Care for the environment is being considered increasingly important and urgent for society, since the future of humanity depends on the relationship between nature and the use of natural resources. The environment is the only source that provides resources for man, allowing him to breathe, live and thrive. With the increase in human capacity to intervene in nature to meet their needs, conflicts and tensions arise regarding the use of spaces and resources in function of the science and technology employed, evolving rapidly with undesirable consequences that worsen over time.

The UN Intergovernmental Conference on Environmental Education held in Tbilisi, Georgia in 1977, emphasizes that it encompasses a number of natural and social elements created by man, and that social elements constitute a set of cultural, moral and individual values, as well as of interpersonal relations the sphere of work and leisure activities [18].

According to [3], it is necessary to recognize that, in order to understand the environmental problem, a complex vision of the environment is necessary, in which nature integrates a network of relations not only natural, but also social and cultural. In this way, environmental education has stood out as a primordial necessity, to acquire a better relationship between man and nature, seeking the concretization of changes in relation to the environment and its reality.

Brazilian law number 9,795, of April 27, 1999, art. 1, environmental education is understood as the processes through which the individual and the community construct social values, knowledge, skills, attitudes and competences aimed at the conservation of the environment, good of common use of the people, essential to the healthy quality of life and its sustainability.

In this context, the application of a formal educational process makes it necessary to apply educational knowledge and practices, focused on day-to-day life at school, reflecting the importance of environmental education as a tool to guide new educational concepts. Based on this assumption, it is not enough to invest in an education focused on knowledge-reason, it is necessary for man to review his values, attitudes, principles, so that he can look at the planet and not only see it objectively, as seeing an object that can be used and thrown away, but can look with other eyes, of whom one delights with such magnitude, beauty, and perfection.

Proposing a work to awaken a critical view of the current environmental situation affects the environment and societies. It is possible to emphasize the importance of working environmental education in elementary school through environmental lyrics that awaken in children this critical look for human actions. 
Therefore, this research has the objective of investigating perspectives of environmental education through music in teacher training. Thus, through music in the classroom, it aims to arouse the interest and participation of students in all activities. Students should engage in the interpretation of music by broadening their understanding of ecological concepts and relationships between living beings and the environment. In addition, the use of music will awaken a critical and reflective sense in relation to environmental issues.

\section{MATERIAL AND METHODS}

This research is oriented by the qualitative approach centered on a participant research. Considering its object of study, Environmental Education, it is intended to have a real understanding through open interviews that precede the data collection with the use of questionnaires.

According to [8], to verify reality makes us capable of intervening in it, an incomparably more complex task generating new knowledge than simply adapting to it.

The purpose of a qualitative research is to intervene in an unsatisfactory situation, to change conditions perceived as transformable, where researcher and researcher voluntarily assume a reactive position [4]. The qualitative research is directed to the analysis of concrete cases in their local and temporal peculiarities, starting from the expressions and activities of the people and their contexts [7].

Action research in environmental education refers to the production of knowledge about reality and about educational processes aimed at transforming this reality, thought and understood [15].

Initially, a bibliographical research was carried out on the theme addressed to support the intended objectives, with the selection of songs to be worked in the classroom in the group of students. For data collection, a questionnaire with 08 questions was elaborated for teachers and students. The questionnaire facilitated the diagnosis of students' perceptions and practices regarding environmental issues. It was used to identify students' prior knowledge about environmental issues.

The questionnaire was only one of the instruments used for the diagnosis. Nothing prevents the teacher from using other tools or making modifications to it, improving it, making it closer to the reality of its students and the school community [10].

The research site was at a primary school in Aliança city, a rural area of the State of Pernambuco, in the Northeast of Brazil. The interviewed subjects were teachers and students of the 9th grade of elementary school II.

\section{RESULTS AND DISCUSSION}

The results were analyzed by content analysis, according to [1]. This methodology tries to critically understand the manifest or hidden meaning of communications, involving, therefore, the analysis of the content of the messages, the utterances of the speeches, as well as the search of the meanings of these messages.

The first question sought to know if any teacher has already used music as a didactic resource in the discipline. How did you use it? $40 \%$ of the students answered yes, with emphasis on the "Portuguese language" chosen by the students as the one that most worked the music in the classroom. On the other hand $60 \%$ commented that teachers do not use music as a resource in class. Music helps to develop students' interest in the subjects by being a common communicative medium, only needing to know how to adapt the songs to the themes of the classes and to promote discussions that enable the development of the teaching-learning process [17]. The training of the teacher should value paradigms that can promote the preparation of reflective teachers, in order to take responsibility for their own professional development and to participate in the implementation of educational policies [12].

In the second question was what most drew attention to the theme of music? It was possible to perceive that the students have knowledge about the environmental theme present in the lyrics of the songs. $63 \%$ of the students said yes, highlighting the following comments: "Pollution is destroying the environment, causing diseases and death of living beings". The other $27 \%$ of the students answered that the earth is dying; the human being is destroying all of nature. The work of teachers has not been enough to reverse the growing process of degradation of the environment caused by modern urban industrial society [9].

For [3] Education happens as part of human action to transform nature into culture, attributing to its senses, bringing it to the field of understanding and human experience of being in the world and participating in life.

Some students demonstrated that they did not know how to interpret the message that the songs wanted to convey about the pollution of the rivers and the deforestation portrayed in the lyrics. It is noticed that there is still some resistance from the students in wanting to know the environmental problems, but they are not to blame for their ignorance of this subject. So changes need to be made, because even if they happen now the benefits will only happen decades later. In this sense, it complements [5] only from the reflection can change of values occur.

In the third question was presented a song with environmental theme. The students were asked which words were related to issues related to the environment. The most frequent words were: pollution, with $47 \%$ of the answers; $40 \%$ for the word earth and $13 \%$ for the word respect. It was from this question that we could perceive how much the music can contribute in the learning of the students. 
The answers given by students about words related to the environment shows the need for man to rethink his interdependence with the environment. It is necessary that the theme be treated at home, in the classroom, in the streets. It should not only perceive it, but act as a multiplier of the information of its perception and its discoveries. Music can be used for the purpose of thinking about processes of social transformation, as well as a fundamental element in the elaboration of fundamental concepts for the area of knowledge [13].

The fourth question was about the knowledge of some music with an ecological approach to the environment? $70 \%$ of the students answered did not have this knowledge and $30 \%$ answered that they know music with this approach. It is important to consider music as belonging to all and as an integral part of the culture of the human being [11]. According to [16], the goal of using music in basic education is to broaden the reach and quality of the students' artistic experience, contributing to a more significant participation in socially produced cultures.

For [6], throughout the existence of man, the practice of associating any discipline with music has always been widely used and demonstrated many auxiliary potentialities in learning. As an example, the use of music by the Jesuits in the process of formation of the good Christian, this culminated in their insertion in the school curriculum in the beginnings of schooling in Brazil.

In this sense, music, when well worked, develops reasoning, creativity and other gifts and aptitudes, so we must take advantage of this rich educational activity within the classroom [14].

According to [5], in order to awaken in students the concern to protect the environment, it is necessary that the qualities of nature and the need to protect the environment in which they live are presented. In the case of the environment, there are great possibilities to find different lyrics of songs that deal with this theme and that can be explored. Natural beauties, as well as degradation to the environment are part of the themes addressed by many composers [17].

The last question in the questionnaire asked for a suggestion on the topic that the students would like to study in the classroom. $57 \%$ of the students answered that they would like to study about preservation of the environment, $37 \%$ answered that they would like to study about reforestation and $6 \%$ preferred to study about the fight against pollution. The water, soil and green mantle of planet earth formed by plants constitute the world that sustains animal life on our planet. Although modern man can hardly remember this fact, he could not exist without plants that capture the energy of the sun and manufacture the food on which it depends to live [2]. Environmental education is a pedagogical practice. This practice does not take place alone, but in the relations of the school environment, in the interaction between different actors, led by a subject, educators [9].

\section{CONCLUSIONS}

In general, the use of music as an aid to teaching is still very insipient in the school investigated. Students claim to feel the lack of this teaching tool. On the other hand, they do not know the symbolic words that represent questions about the environment.

Environmental education can be worked as an element of transformation of the school, individuals and society. But teachers need to be prepared to explore the potential of music.

It is hoped that the research will contribute to the implementation of changes in the environmental practices of students who work in fundamental education in this broad subject that is environmental education.

\section{REFERENCES}

[1] Bardin. L. (2011). Análise do conteúdo. São Paulo: Edição 70. 229p.

[2] Carson, R. (2010). Primavera Silenciosa, $1^{\text {a }}$ edição, São Paulo: Gaia. 228p.

[3] Carvalho, I.C.M. (2012). Educação Ambiental a Formação do Sujeito Ecológico, 6a edição, São Paulo: Cortez. $256 p$.

[4] Chizzotti, A. (2003). Pesquisa em Ciências Humanas e Sociais. $6^{a}$ edição; São Paulo: Cortez. 164p.

[5] Evaristo, J.A. (2010). Um estudo sobre a educação ambiental proposta no PCN. 44 fls. Trabalho de Conclusão de Curso

(Graduação em Pedagogia). Universidade Estadual de Londrina.

[6] Ferreira, M. (2008). Como usar a música na sala de aula. 7. Ed. São Paulo: Contexto. 240p.

[7] Flick, U. (2009). Métodos de Pesquisa Introdução a Pesquisa Qualificada. $3^{a}$ edição, Porto Alegre. 256p.

[8] Freire, P. (1997). Pedagogia da Autonomia: Saberes necessários à prática educativa. Coleção leitura. Rio de janeiro:

Paz e Terra. 54p.

[9] Guimarães, R.B. (2011). Metodologia e Projetos: Uma proposta para o ensino da Geografia. Presidente Prudente.

[10] Lisboa, C.P.; Kindel, E.A.I. (2012). Educação Ambiental da Teoria a Prática. Porto Alegre: Mediação. 144p.

[11] Mateiro, T. \& Ilari, B. (2011). Pedagogias em Educação Ambiental. $1^{a}$ edição, Curitiba.

[12] Nóvoa, A. (1997). Formação de professores e profissão docente. In: ___ (Org.). Os professores e sua formação. $3^{\mathrm{a}}$ ed. Lisboa: Dom Quixote, p.13-33.

[13] Oliveira, A.R. (2002). A música no ensino de língua portuguesa. PUBLICATIO UEPG- Ciências Humanas, C. Sociais Aplicadas, Linguística, Letras e Artes, 10 (1): 73-84. 
[14] Orange, C.F.; Silva, C.S.; Ricci, S.M. (2016). A importância da música na aprendizagem. Acadêmicas do $2^{\circ}$ ano do curso de Pedagogia (2006) UNIMEO/CTESOP. Avaiable in: 〈http://www.alexandracaracol.com/ Ficheiros/music.pdf>. access in: 20 January 2016.

[15] Pedrini, A.G.; Saito, C.H. (2014). Uma luz inicial no caminho metodológico da Educação Ambiental. In: Alexandre de Gusmão Pedrini; Carlos Hiroo Saito. (Org.). Paradigmas metodológicos em educação ambiental. 1ed. Petrópolis: Vozes, p. 37-43.

[16] Penna, M. (2014). Música(s) e seu Ensino. Porto Alegre: $2^{\mathrm{a}}$ edição, Sulina.

[17] Pinheiro, E.A.; Mendonça, B.A.; Silva, G.J.; Gonçalves, O.O.; Chaves, T.S. (2004). O Nordeste brasileiro nas músicas de Luiz Gonzaga. Caderno de Geografia: PUCMINAS, Belo Horizonte, v. 14, n. 23, p. 103-111, $2^{\circ}$ sem.

[18] Ruscheinsky, A. (2012). Educação Ambiental Abordagens Múltiplas. 2a edição, Penso. São Paulo. 312p. 